\title{
Economics of Jatropha Plant Production in Guma Local Government Area of Benue State.
}

\author{
Ezihe, J.A.C., GAMBA, V. and Kingsley, I. H. \\ Department of Agricultural Economics University of Agriculture, Makurdi, Benue State, Nigeria
}

\begin{abstract}
The study analyzed the economics of Jatropha plant production in Guma Local Government Area of Benue State, Nigeria. This is with the view to analyzing cost and return and constraints that influence Jatropha plant production. A purposive sampling and simple random sampling techniques were used to collect data from 100 Jatropha plant farmers using well structured questionnaire. Descriptive statistics and the gross margin analysis were used as method of data analysis. The socio-economic characteristics of respondents revealed that majority (68\%) of the respondents were male, the respondents fall within the age range of 21-40 years and majority (87.6\%) were married. The results showed that Jatropha plant farmers were moderately educated and small scale farmers with household of 1-10 family members and annually income of 1000-50000. The mean gross margin for the Jatropha plant production was 84166.4168 which implies Jatropha plant farmers in the study area get an annually return of 84166.4168. The result also revealed that, the prevailing constraints militating against Jatropha plant production in the study area was inadequate capital and it represented $99 \%$ of the major constraint affecting the economic sustainability of Jatropha plant in the study area. The study therefore, recommended that large scale production of Jatropha plants should be encouraged both by the government and farmers' cooperative to boost the economics of the State as well the entire nation as Jatropha plant production was profitable in the study area.
\end{abstract}

Keywords: Jatropha plant, production, profitability, family Euphorbiaceous.

\section{Introduction}

The indispensability of plant to man and the development of economies of nations can be traced to antiquity. The economic variability of plants to man and the general well being of the ecosystem as well as the growth and the sustenance of nation cannot be overemphasized. Plants serve as pertinent sources of raw material for our industries, as well as the provision of medical values to mankind and the provision of alternative sources of energy amongst others too myriad to mention (Aderibigbe et al., 1997). One of such feedstock plants of contemporary importance is Jatropha curcas linnaeus. Jatropha curcas is a drought resistant perennial species of flowering plants in the spurge family Euphorbiaceous that is native to the American tropics most likely Mexico and Central American (Achten et al., 2010). It is planted in the tropical and subtropical region around the World, becoming naturalized in some area. Jatropha is a poisonous plant reaching a height of $6 \mathrm{~m}$ (20ft), with seeds which contain $27-40 \%$ oil that can be processed to produce a high quality biodiesel fuel, usable in a standard diesel engine or further processed into jet fuel while the residue pressed cake can also be harnessed as biomass feedstock to power electricity plants, used as organic fertilizer which is composite of nitrogen, phosphorus and potassium or as animal fodder, the cake can also be used as feeds in the digesters and gasifies to produce biogas (Borman, 2011). Medically, it is used for the treatment of diseases such as cancer, pile, snake bite, paralysis and drowsy. Oil extracts of jatropha has been used for illuminations, soap candle and the seeds are used as contraceptive in south Sudan (GANBC, 2012).

The agricultural sector has been proven to be four times successful in poverty reduction and improving livelihood with the production of Jatropha. Again, the rising the demand for oil, speculation for diminishing reserves, fuel price instability, the consequence growing needs for energy security and incited global efforts to develop capacity for alternative source of energy provision which has also accentuated the relevance and economic priceless of Jatropha (Achten et al., 2007). The production of Jatropha plant tends to generate high level of rural employment, improvements of national balance of trade and stimulation of both agricultural and non agricultural sector associated with the Jatropha biodiesel production chain (Heller, 1996). The plant itself is believed to prevent and control soil erosion and reclaim of agricultural wastelands as well as the provision of fence for excluding livestock from food crops as Jatropha is highly unpalatable (Borman, 2011). Despite these colossal contribution of Jatropha plant in the development of economies of nation, the production and understanding of the agronomy of this influential plant is quite worrisome due to the risk involves in its production as it is a poisonous plants. 


\section{Objectives of the study}

The specific objectives of this study were to:

- Describe the socio-economic characteristics of respondents in the study area.

- Determine the profitability of Jatropha plants production in the study area.

- Ascertain the constraints militating against Jatropha plants production in the study area.

\section{Material and Methods}

The study Area: This study was conducted in Guma Local Government Area of Benue state, Nigeria. The Local governments is situated on the North Eastern parts of Benue State and has a land mass of about 2400square kilometers and shared boundaries with Makurdi Local Governments in the south, Tarkaa and Buruku in the south-east, Logo Local government to the east and two Local governments in Nasarawa State vie Awe in the North-East and Doma in the north-west. The State lies between longitude $6^{\circ} 35^{\prime} \mathrm{E}$ and $8^{\circ} 10^{\prime} \mathrm{E}$ of the Greenwich and latitude $6^{0} 30^{\prime} \mathrm{N}$ and $8^{0} 10^{\prime} \mathrm{N}$ of the equator, at an elevation of 97 meters above sea level in the southern guinea savannah agro ecological zone. The State is located in the north central zone of Nigeria and is referred to as the "food basket of the nation" because of the facts that it is major producer of food in Nigeria. Major crops produced in the State include: cassava, yam, rice, benniseed, maize, sweet potatoes, millet, soybean, and a wide of tree crops like mango, citrus, oil palm and banana. Others include livestock production.

Data collection: The population for this study comprised all Jatropha farmers in Guma Local Government Area of Benue State, Nigeria. Purposive sampling technique was used to select the Local Government Area because of the farmers' concentration in the Jatropha plant production. To effectively carry out the research a simple random sampling technique was also adapted to selects ten (10) respondents each from the ten (10) council area of Guma Local Government using well structured questionnaire and this give rise to 100 respondents.

Method of Data Analysis: Descriptive statistics like mean, percentage and frequency distribution were used to describe the socio-economic characteristics of the respondents and gross margin was used to analyze the profitability of Jatropha plant in the study area.

Empirical Specification: The gross margin is the differences in the gross farm income (GI) and the total variable cost (TVC). It is also the differences between total revenue and total variable cost.

$\mathrm{GM}=\mathrm{GI}-\mathrm{TVC}$ or TR-TVC

Where:

$\mathrm{GM}=$ Gross margin

$\mathrm{GI}=$ Gross farm income

$\mathrm{TVC}=$ Total variable cost

$\mathrm{TR}=$ Total revenue

\section{Socio - Economic Factors of The Jatropha Farmers}

The result of the analysis presented in table 1 indicates the majority (68\%) of the Jatropha farmers were males while $32 \%$ were females. This shows that most of the farming activities were headed by men who are believed to be more energetic to practice Jatropha production than their women counterpart. The results also shows that $87 \%$ of the respondents of Jatropha famers in the study area were married while $31 \%$ were single, 9.3\% were widows/widower and no divorced farmers. This result implies that Jatropha plant production in the study area is also done by married people other than category of people. About $27.8 \%$ of the farmers had no formal education while $20.6 \%$ and $36.1 \%$ had primary and secondary education respectively. The remaining $15.5 \%$ of the Jatropha farmers had tertiary education. This shows that majority $(51.6 \%)$ of the respondents are educated implying that there is moderate level of literacy among Jatropha famers in the study area which will enable farmers to better adopt farm practices that will enhance the Jatropha plant production. Meanwhile, $94.8 \%$ of the Jatropha farmers' households had $1-10$ members, 4.1\% had $10-20$ members and $1 \%$ had $20-30$ occupied by $1-10$ family members. This implies that family size of Jatropha farm households in the study area are relatively small and as such would produce Jatropha on small scale.

The result revealed that $3.1 \%$ of the farmer had a farm lands of 0.01 hectares, $30.9 \%$ of the respondents had lands of 0.1 hectare, $28.9 \%$ of the farmer had farm lands of 0.2 hectares, $21.6 \%$ of the farmer had farm lands of 0.25 hectare, $8.2 \%$ of the farmers had farm lands of 0.5 hectares $6.2 \%$ of the farmers had farm land lands of 1 hectares and $1.0 \%$ of the farmer had farm land of 2 hectares. The result connotes that Jatropha plant production are small scale farmers. This agrees with the findings of Odoemenem and Adebisi (2011) who reported that the mean farm size for small-scales farming in Nigeria is often less than four hectares. The age distribution of Jatropha farmers in the study area as shown in table 1 reveals that all the farmers were above 20 years with 
majority $51.5 \%$ falling between $41-60$ years. While $29.9 \%$ were between $21-40$ years, $18.6 \%$ were above 60 years. This implies that most $(81.4 \%)$ of the Jatropha farmers belonged to the age group of 21-60/ ears which connotes that they are within the productive age of 2-060 years as opined by Onu (2003) who reported that age is a very important measure of production which is capable of affecting either positively or negatively the output of per labour input of a famer. Furthermore, result reveals that most of the respondents $(94.8 \%)$ earning between N1000- 5000 annually, 2.1\% earned between 5001-10000 per annum and 3.1\% earned between $\$ 10001-20000$. This disagree with the view of Olawepo (2010) found that only $13.80 \%$ of small scale farmer such as Jatropha in Guma earn above 50,000 annually.

\section{Profitability of Jatropha Plant Production in the Study Area}

Table 2 present the results of gross margin analysis for Jatropha plant production. The results indicated that the average total variables cost for Jatropha production was 7279.4595 and the mean total revenue earned from the production of Jatropha plant as found to be 791,445.8763. Similarly, mean gross margin of \$84,166.4168 was estimate for Jatropha plant production which implies that Jatropha plant farmers in the area get an annual return of 84,166.4168 from the production process. Therefore, Jatropha plant production was discovered as a viable economic venture in the study area. This is capable of addressing the various needs of the rural farmers thereby improving the living standards of the farmers.

\section{Constraints Militating Against Jatropha Production}

From the results of the statistical analysis presented in table 3, it is revealed that Jatropha production in the study area not constrained by lack of available markets, low patronage and insufficient land since all (100\%) the Jatropha farmers responded not having any problem with the issue of market and land availability for Jatropha production as well as patronage for the product. However, 99\% of the farmer mentioned back of capital as the only militating constraints of Jatropha $\mathrm{p}$ ant production. The result therefore is an indication that inadequate capital is the major (99\%) prevailing problem or constraint militating against the economic sustainability of Jatropha plant production in the area. This agrees with Obwona (2002) who reported that the most of the Nigeria farmers are small holders who are trapped in vicious cycle of poverty that is characterized by low saving and investment which causes reduction' in the production capacity of the farmers.

\section{Conclusion and Recommendation}

The study revealed that Jatropha plant production was discovered to be a lucrative economics enterprise in the study area which is capable of addressing the needs of the rural farmers thereby increases the living standard of the populace in the study area since the result have revealed the profitability of Jatropha plants production. The study recommended large scale production of the plants as it will boost the economy of the state. It also recommended that governments and other financial institution should key into the production by providing loans to farmer and other credits facilities. Constants seminar on the function and uses of the plants should be encourage among the farmers.

Table 1: Socio Economic Characteristics of the Respondent

\begin{tabular}{|l|l|l|}
\hline Variables & Frequency & Percentage \\
\hline Gender & & \\
\hline Male & 66 & 68.0 \\
\hline Female & 31 & 32.0 \\
\hline Total & 97 & 100 \\
\hline Age & & \\
\hline$>60$ & 18 & 18.6 \\
\hline $21-40$ & 29 & 29.9 \\
\hline $41-60$ & 50 & 51.5 \\
\hline Total & 97 & 100.0 \\
\hline Marital Status & & \\
\hline Married & 85 & 87.6 \\
\hline Single & 3 & 3.1 \\
\hline Widow/Widower & 9 & 9.3 \\
\hline Total & 97 & 100.00 \\
\hline Educational level & & \\
\hline No formal education & 27 & 27.8 \\
\hline Primary education & 20 & 20.6 \\
\hline Secondary education & 35 & 36.1 \\
\hline Tertiary education & 15 & 15.5 \\
\hline Total & 97 & 100.00 \\
\hline Household size & & \\
\hline $1-10$ & 92 & 94.8 \\
\hline $10-20$ & 4 & 4.1 \\
\hline
\end{tabular}




\begin{tabular}{|l|l|l|}
\hline $20-30$ & 1 & 1.0 \\
\hline Total & 97 & 100.00 \\
\hline Farm Land (Ha) & & \\
\hline 0.01 & 3 & 3.1 \\
\hline 0.1 & 30 & 30.9 \\
\hline 0.2 & 28 & 28.9 \\
\hline 0.25 & 21 & 21.6 \\
\hline 0.5 & 8 & 8.2 \\
\hline 1 & 6 & 6.2 \\
\hline 2 & 1 & 1.0 \\
\hline Total & 97 & 100.00 \\
\hline Income & & \\
\hline $1000-5000$ & 92 & 94.8 \\
\hline $5001-10000$ & 2 & 2.1 \\
\hline $10001-20000$ & 3 & 3.1 \\
\hline Total & 97 & 100.0 \\
\hline
\end{tabular}

Source: Field survey, 2015

Table 2: Result of gross margin analysis for Jatropha production

\begin{tabular}{|l|l|l|l|l|}
\hline Variable & Minimum & Percentage & Mean & Standard Deviation \\
\hline Total variable cost & 1920.00 & 14420.00 & 7279.4595 & 2905.31723 \\
\hline Total Revenue & 1400.00 & 2040000.00 & 911445.8763 & 2.27042 \\
\hline Gross Margin & -520.00 & 2025580 & 84166.4168 & -2903.0468 \\
\hline
\end{tabular}

Source: Field Survey, 2015

Table 3: Descriptive Statistics of the Constrain Militating Against Jatropha Production

\begin{tabular}{|l|l|l|}
\hline Constraints & Frequency & Percentage \\
\hline Lack of capital & 5.4 & 5.48 \\
\hline No problem of land availability & 1.0 & 1.01 \\
\hline No problem of available market & 1.4 & 1.46 \\
\hline No problem of patronage & 6.0 & 6.01 \\
\hline Total & 2.2 & 2.21 \\
\hline
\end{tabular}

Multiple Responses. Source: Field survey, 2015

\section{References}

[1] Achten, W.M.J., Maes, W.H., Aerts, R., Verchot, L., Trabucco, A., Miathij, E., Singh, V.P., Muys, B. (2010). Jatropha: from global hype to local opportunity. Journal of arid environments 74:164-165.

[2] Achten, W.M.J., Miathij, E., Verchot, L., Singh, V.P., Aert, R. and Muys, B. (2007). Jatropha biodiesel fueling sustainability? Biofuels bio-products and refining, 1: 283-291.

[3] Aderibigbe, A.O., Johnson, C.O.L.E., Makkar, H.P.S., Becker, K. and Foit, N. (1997). Chemical composition and effects of heat on organic matter and nitrogen-degradability and some anti-nutritional component of Jatropha meal. Journal of animal science and technology, 67:223-243.

[4] Borman, G. D. (2011). An assessments of the economic sustainability of Jatropha- based Biodiesel initiatives: implication for labour and rural livelihood. A dissertation submitted to the faculty of science, University of the Witwatersrand, Johannesburg, South Africa.

[5] Heller, J. (1996). Physic nut Jatropha curcas L. promoting the conservation and use of underutilized neglected crops, Phd dissertation, institute of plant genetic and crop plant research, Gatersleben, Germany and international plant genetic resource institute, Rome, Italy.

[6] Obwona, M. (2002). Determinant of technical efficiency amongst small and medium scale farmers in Uganda: A case tobacco growers. Economics policy research centre (EPRC) Uganda. Pp. 19-24.

[7] Odoemenem, I.U., Adebisi, V. (2011). Sustainable agricultural for small scale farmers in Niger State, Nigeria. Journal of sustainable development 13(2): 226

[8] Olawepa, R.A. (2010). Determining rural farmers income: a rural Nigeria experience. Journal of Africa studies and developments 2(2): $15-26$

[9] Onu, S. (2003). Credite acquisition and utilization by small scale farmers in Benue State, Nigeria: A case study of Makurdi Local Government Area. Unpublished B.agric. Projects, Departments of Agricultural economic and Extension University of agriculture, makurdi: pp31-33

[10] The global authority on non food biodiesel crops (2010). Available from http:/ www.jatrophabiodiesel.org/about jatrophaplant .php?. Retrieved on june 16, 2014. 